\title{
LOVE AND RATIONALITY. ON SOME POSSIBLE RATIONAL EFFECTS OF LOVE
}

\author{
Gustavo Ortiz-Millán* \\ gmom@filosoficas.unam.mx
}

\begin{abstract}
In this paper I defend the idea that rather than disrupting rationality, as the common-sense conception has done it, love may actually help us to develop rational ways of thinking and acting. I make the case for romantic or erotic love, since this is the kind of love that is more frequently associated with irrationality in acting and thinking. I argue that this kind of love may make us develop epistemic and practical forms of rationality. Based on an analysis of its characteristic action tendencies, I argue that love may help us to develop an instrumental form of rationality in determining the best means to achieve the object of love. It may also narrow down the number of practical considerations that may help us to achieve our goals. Finally, love may generate rational ways of belief-formation by framing the parameters taken into account in perception and attention, and by bringing into light only a small portion of the epistemic information available. Love may make us perceive reality more acutely.
\end{abstract}

Keywords Erotic Love; Emotions; Practical Rationality; Epistemic Rationality

RESUMO Neste artigo defendo a idéia de que, em vez de perturbar a racionalidade, como a concepção do senso comum o faz, o amor pode, na verdade, ajudar-nos a desenvolver modos racionais de pensar e agir. Dou bons argumentos para o amor romântico ou erótico, uma vez que esse é o tipo

* Instituto de Investigaciones Filosóficas, Universidad Nacional Autónoma de México. Artigo recebido em maio de 2006 e aprovado em julho de 2006.

KRITERION, Belo Horizonte, nº 115, Jun/2007, p. 127-144. 
de amor que é mais freqüentemente associado à irracionalidade no agir e no pensar. Argumento que esse tipo de amor pode fazer-nos desenvolver formas epistêmicas e práticas de racionalidade. Com base em uma análise de suas tendências características para a ação, argumento que o amor pode ajudar-nos a desenvolver uma forma instrumental de racionalidade para se determinar o melhor meio de atingir o objeto de amor. Ele também pode limitar o número de considerações práticas que podem ajudar-nos a atingir os nossos objetivos. Finalmente, o amor pode gerar modos racionais de formação de crenças ao estruturar os parâmetros considerados na percepção e na atenção e ao revelar somente uma pequena parcela da informação epistêmica disponível. $O$ amor pode fazer-nos perceber a realidade de um modo mais vivo.

Palavras-Chave Amor Erótico; Emoções; Racionalidade Prática; Racionalidade Epistêmica

Lovers and madmen have such seething brains,

Such shaping fantasies, that apprehend

More than cool reason ever comprehends.

Shakespeare, A Midsummer Night's Dream, act V, scene 1

1. According to an old commonplace, emotions are potential disrupters of rationality. Traditionally, people have thought that emotions are impulses or urges that interfere with our capacity to form rational judgments and beliefs, and with rational action more generally. Rationality and emotions, we are told, form part of a duality in which both appear to have very clear and separate realms. The notion of rationality seems to preclude any involvement of emotions; emotions are a paradigm of unreflective and subjective motives, and whenever they appear in the justification of our judgments and actions, that is reason enough for suspecting that this justification may not be objective or guided by logic and proper reflection. To be sure, this view, the received view, is true in many cases: emotions may perturb clear and rational thinking, but it is no less true that they also have a role as parts of rational thinking without which the latter would very likely not work. Recent studies in neurophysiology, for instance, have shown that emotions and feelings are the system of support without which the building of reason would not work properly and might even collapse: rational decisions require the support of emotions and feelings, and not only of logic. ${ }^{1}$ Emotions are part of our reflective thinking because they are 
reasons for action and for judging as much as beliefs, desires and intentions are. Actually, emotions are among the most common reasons that we have for acting; without them, we would probably have few reasons for acting.

In this paper I want to defend the idea that, rather than disrupting rationality, certain emotions may actually help us to develop rational ways of thinking and acting; that is, I intend to challenge the received view that sees rationality and emotions as completely at odds with each other. I am not saying that emotions can always yield rational effects on behavior, because this is obviously not true. The effects on rationality that some emotions may have are contingent on particular circumstances. There is truth in the traditional view that sees emotions as disrupters of rationality; but if this mechanism of disruption takes place more often than not, the opposite mechanism, that of aid to rational thinking, seems to be also effective in a number of cases. Mechanisms, as Jon Elster defines them, are "frequently occurring and easily recognizable causal patterns that are triggered under generally unknown conditions or with indeterminate consequences. They allow us to explain, but not to predict."” There are recognizable causal patterns triggering the effects of emotions, but these effects are indeterminate, and most of the time impossible to predict. It is hard to rely on any kind of law-like explanation for when emotions take one role and when the other, or to make generalizations about the conditions that would lead to one or the other effect.

I do not intend to generalize my thesis for all kinds of emotions, especially since I suspect that it does not apply to all emotions, like those characterized by very visceral reactions, such as fury or panic. Since emotions are so diverse I am going to limit my claim to the case of love. Perhaps some of the conclusions that I hope to reach here would also apply to other emotions. I am not going to attempt to develop any meticulous articulation of the nature of love and I am not even going to talk about the different kinds of love that we may find, particularly since it is such a multifaceted and diverse emotion. There are several kinds of love and not all of them work in the same way or are manifested in the same manner. Maternal love is not the same as romantic love, brotherly love, self-love or love of God. Because of the connotations of irrationality that it traditionally carries, I have preferred to focus on erotic or romantic love, and I want to challenge this aspect of the received view that sees it as inexorably linked to irrationality. I have chosen this kind of love because, unlike the other kinds of love that I have mentioned, this kind is the one that, in the minds of many people, more clearly has associations with 
sexual desire, lust, concupiscence, and with those lower passions that make us lose control of ourselves, and go head over heels. From now on, my use of the word "love" will refer to erotic or romantic love. Perhaps some of the things that I am going to say about it may be extended to other forms of love, but I am not assuming so.

Now, it is difficult to talk about love as if it were isolable from other emotions; it is good to keep in mind that some of the effects that I am going to attribute to love usually have the intervention of other emotions, such as joy, jealousy, fear, shame, hope or even hatred - since love and hatred seem to be so close to each other at many points in our lives. Pure emotions are hard to find in our emotional and mental life.

The received view of love has emphasized its irrational effects. It tells us that to be in love is a way of losing control of oneself, of going into pieces, that love makes people stupid - of course, it is fair to say that this is just one aspect of the received view, but a very influential one. It is no coincidence that we even say in English "to fall in love" when one is overcome by love: to be in love is to fall from the right way of reason, it may lead us out of ourselves, towards a lack of good sense, understanding, or foresight. It may even lead to self-destruction, craziness and irrationality. Ruth, one of the hundreds of people interviewed by Dorothy Tennov in her classic book about the experience of being in love, put this thought in the following way: "Love is irrational. Whether you call it a mental illness or sublime spirituality, you behave in love in ways that do not represent your own true best interests, ways that deflect from the goals you've built your life around, even if the deflection is slight, even if it is easily rationalized and even when it is disguised as beauty or experienced as ecstasy." "' Love has traditionally been regarded in this way: as insanity, as losing control over oneself, as a force that does not let us think straight, and that make us deceive ourselves and even distort our perception of reality. Robert Graves gives us a different version of this commonplace in these verses: "Love is a universal migraine, / A bright stain on the vision / Blotting out reason." All this is true, no doubt about it, but only partially true. In these few verses, Graves gives me a good formulation of the ideas that I want to develop here, though in an opposite way. Love may not only be no stain on the vision, blotting out reason, but it may facilitate the former, while developing the latter. 
2. Love may help to develop rationality in both its practical and its epistemic modalities - if one accepts this analytical distinction, which I adopt here for expository purposes. I shall leave the effects of love on epistemic rationality for the next section. In this section, I shall analyze the simplest form in which love may affect practical rationality: by developing an instrumental kind of rationality. When talking about practical rationality I shall refer mostly to instrumental rationality. In its character as a reason for action, love sets the goals of our actions paving the way for a means-ends way of thinking. Love has characteristic action tendencies that fix the goals of our actions.

Although my main aim is to talk about how love may develop rational ways of acting, love in itself is open, at least in part, to rational evaluation and control. This might be claimed about almost any emotion. Emotions have cognitive and evaluative antecedents and this makes them, to a certain extent, assessable in rational terms. ${ }^{4}$ I say "to a certain extent" because there is a subjective component to emotions that cannot be accounted for in terms of reasons, but in terms of subjective feelings or qualitative feels. In the case of love, this emotion involves beliefs and value judgments about the object of love: the judgment, for instance, that the other person is beautiful, or nice, or attractive, or more generally, that the other person is lovable. These beliefs and evaluations count as reasons for having such an emotion - of course, reasons may be good or bad. ${ }^{5}$ Yet, there seems to be a gap between our holding reasons for having an emotion and actually having it - maybe this is due to the subjective component of emotions. Love does not entirely depend on reasons in the same way as beliefs or some of our desires do. An agent may have the best reasons for being in love with somebody, even from his own point of view, and nevertheless not fall in love. Even if she is, say, the most convenient

However, emotions are not exclusively constituted by cognitive states, they have specific characteristics that help us to distinguish them from beliefs, or from desires: qualitative feel, physiological arousal and expressions, valence on the pleasure-pain dimension, and characteristic action tendencies. See Alchemies of the Mind (pp. $246 \mathrm{ff}$ ) for a broader characterization of emotions in these terms; see also ELSTER. Strong Feelings. Emotion, Addiction, and Human Behavior. Cambridge, MA: The MIT Press, 1999, p. $26 \mathrm{ff}$.

5 However, D.W. Hamlyn has argued that love is compatible with any kind of beliefs, whether negative or positive. See: HAMLYN. The Phenomena of Love and Hate. In: Perception, Learning and the Self. London: Routledge and Kegan Paul, 1983. Compare also with what Harry Frankfurt tells us: "Love may be brought about - in ways that are poorly understood - by a disparate variety of natural causes. It is entirely possible for a person to be caused to love something without noticing its value, or without being at all impressed by its value, or despite recognizing that there really is nothing especially valuable about it. It is even possible for a person to come to love something despite recognizing that its inherent nature is actually and utterly bad. That sort of love is doubtless a misfortune. Still, such things happen." (FRANKFURT, The Reasons of Love, Princeton: Princeton University Press, 2004, p. 38). 
person for the agent or the one he admires the most, he may not fall in love with her. Love just doesn't happen.

An emotion may be rationally "appropriate" depending on its object and on the circumstances in which it appears; and our rational assessment of it is about when it makes sense to have it or not, and about the role we let it play in our lives. The object of our love may be assessed in rational terms depending on the general context of our life in which it appears, that is, in the context of the goals and life plans around which we have constructed our life. It might be argued that somebody may just not be convenient for us given the kind of persons we are, our goals or our specific circumstances. However, love does not always seem to care about these reasons - just think, for instance, about the love of professor Rath for Lola Lola in Heinrich Mann's The Blue Angel, a passion that ends up having destructive effects on the lover, and that we could certainly call an irrational love. Thus, an emotion in itself can be assessed in terms of its appropriateness in relation to its object and surrounding circumstances. But at other times the love of a person may be judged as irrational, not because the emotion he experiences is itself irrational, but because of the role he allows it to play in his life. For instance, a person who is led by love to such a degree that he misses out on some experiences or benefits that life has to offer.

Let me now turn to the role that love may play in developing strategic or instrumental forms of rationality. In belief-desire models of instrumental rationality, a desire is usually regarded as the state that sets the goals of our actions, and beliefs just play a role in determining the means through which those ends are going to be achieved. When emotions get into this picture, they tend to be viewed as interfering with the process of deliberation through which we achieve our goals. But sometimes emotions and desires are bunched together given, among other things, their alleged character as drives that push us to action. In that sense, both play similar roles in setting the goals of our actions. But the roles they play in practical rationality when an emotion, and more particularly love, is involved are different, so let me make clear the point about the relationship, and the differences, between love and desire: it is not that she who is in love looks for the love of the other person because she wants to see her desire satisfied. ${ }^{6}$ It is rather that, because she actually loves the other person and wants to see her love reciprocated, she looks for the joy and the well-being of the beloved, and she does certain things and behaves in certain 
ways to get the attention of the other person and have her love reciprocated or just be with the loved one. Thus, it is not desire that sets the goals that are going to determine our deliberation and conduct, but love. Love determines our desire, and not the other way round. When love is implicated as a reason for action, the starting point of practical deliberation, so to speak, is love, not desire. Love, though, generates certain characteristic desires - we can even say that it is constituted, among other things, by certain desires. However, the boundaries between love and desire (as well as other emotions and more generally other mental states) are not clear-cut and it is not always easy to distinguish them; sometimes what passes for love may actually be some form of sensuous desire or lust. For the sake of the argument, let me assume that love is not only different from desire in general, but also from the sensuous desires love may generate. This sensuous desire, or lust, is independent of love - although it may be brought about by it. I take it that love and desire have a distinct phenomenological character.

In general, and when not interfered with by other emotions, love has three characteristic action tendencies, which we can also identify with the kinds of desires that it may generate: (1) the desire for reciprocation, (2) the desire to benefit, and (3) the desire to be with, the beloved. ${ }^{7}$ Let me analyze these action tendencies in two different moments of the romantic relationship. The first moment in which this takes place is when love is making us behave in certain ways in order to get the attention and the love of the loved one; a second moment will come once the love of the other person has been achieved and one is seeking to maintain it.

When someone loves another person, there is generally an acute longing for reciprocation - one wants to get her love in return. The lover will look for reciprocity to his love, and here is where a kind of Hobbesian reckoning of consequences makes its appearance: in the form of tactics and strategies in which we balance the means that we are going to use to attain the goals fixed by love - if rational, the lover will choose that action with the highest expected utility. Here, love also appears combined with hopes of reciprocity and fear of rejection. Unrequited loves usually cause suffering and pain - just think about

7 Tennov includes also the desires to be where the loved person is likely to be, the desire to talk about the loved person, and to be alone thinking about the beloved (op. cit., p. 121). Another characterization of the action tendencies of love is given by Gabriele Taylor: "If $x$ loves $y$, then $x$ wants to benefit and be with $y$, etc., and has these wants (or at least some of them), because he believes $y$ has some determinate characteristics $\psi$ in virtue of which he thinks it is worth while to benefit and be with $y$. He regards satisfaction of these wants as an end and not as a means towards some other end." (TAYLOR, Love. Proceedings of the Aristotelian Society 76 [1975-1976], p. 157.) See also FRANKFURT. The Reasons of Love. Princeton: Princeton University Press, 2004. 
Cyrano, the Portuguese nun or the 15-year-old girl who is madly in love with a guy who doesn't even know she exists. In general, lovers try to avoid the pain and suffering of not seeing their feelings returned, and this forces them to look for strategies that help them gain the heart of the beloved - one may even devise strategies through which to protect oneself in case of rejection.

The strategies of love may emerge perhaps even before the appearance of love, with the desire to be in love, through trying to put oneself in a position where it is more likely that one finds the love desired. It has been claimed that love and the dating scene are a sort of marketplace and that there is a kind of shopping involved in it. The possible shopper will look for the smartest, kindest, funniest, or most attractive person available; she knows, or should know, that the same criteria apply to herself and may thus try to enhance or accentuate what she takes to be her best features in order to win the attention of others. The person who seeks love may try to behave in ways that attract the attention of potential partners. Although there is no guarantee of gaining their attention, the love-seeker knows that by enhancing those characteristics that she takes to be her best assets she increases the probability of impressing these potential partners and getting what she desires. Things are not that different for the person who is attracted to somebody or who has already fallen in love: he may try to behave in ways that please the loved one, and win her attention: maybe by getting trim, by being more careful of his attitudes and about what he says, or maybe even by following Ovid's advice for conquering and maintaining the love of women. Love, it is claimed, may produce miracles in people: it may turn them into attentive, sensible, formal, prudent or non-selfish people. In a certain way, love civilizes-although not just any rationalizing process counts as a civilizing one, in this context "rationalize" and "civilize" may in fact be taken as synonyms. In one of the stories of his Decameron, Boccaccio tells us the story of Cymon, a stupid man who is turned into a intelligent one by love:

Now that Cymon's heart, which no amount of schooling had been able to penetrate, was pierced by Love's arrow through the medium of Iphigenia's beauty, he suddenly began to display a lively interest in one thing after another, to the amazement of his father, his whole family, and everyone else who knew him. He first of all asked his father's permission to wear the same sort of clothes as his brothers, including all the frills with which they were in the habit of adorning themselves, and to this his father very readily agreed, he then began to associate with young men of excellence, observing the manners befitting a gentleman, more especially those of a gentleman in love, and within a very short space of time, to everyone's enormous stupefaction, he not only acquired the rudiments of letters but became most eminent among philosophic wits. (...) In short (without going into further detail about his various accomplishments), in the space of four years from the day he had fallen in love, he 
turned out to be the most graceful, refined, and versatile young man in the island of Cyprus. ${ }^{8}$

Love, as Boccaccio tells us, may even turn stupid people into intelligent and philosophic ones - but we might say that the opposite is also sometimes true. It is true that the mood of the person in love changes, but also, in order to see one's love reciprocated, sometimes one has to change certain character traits, habits, personal appearance, or do those things one thinks would please the other person (but as we all know, nothing guarantees that these effects may last after one has already reached the object of desire, or once love fades: they may last as long as love lasts). When in love, we may try to display our best characteristics, what we feel is most ours, most true, and we want this to be appreciated in order to get the love of the other person. This is also what is behind the idea of courtship, that is, of trying to gain the love of another person by following certain strategies of ploys and flirting. The person in love has to figure out some courting or dating strategies, that is, plans of action directed at accomplishing the goal of winning other person's love. A dating strategy would consist in finding the best possible means to achieve this goal. Courting and flirting, as any manual on the subject would tell us, are skills that one can develop, consisting of strategies for attracting others and getting one's love reciprocated. This requires the ability of knowing when to make a move, and when not to; of knowing what to do when one does not get the response one wants; of knowing how to decipher body language; how to overcome one's fears and shyness, and so on. But these are just some of the means that tend to promote the achievement of one's goals. If one is not a Don Juan and is not merely moved by the thrill of seduction, but by love, then it is this emotion, and not some other attitude, that fixes the goals of one's actions. The lover does not love in order to get some ulterior end, satisfy some desire or need (or not exclusively because of this); love and the desire generated by it do not have any other end than having one's love reciprocated, benefiting and being with the beloved.

If one is lucky and one's love is reciprocated, once the other person's love has been attained, our love requires of us that we behave in ways adequate to it so as to maintain the object of our affection. Love imposes some practical demands on the lover. Since love is a way of caring about the beloved, it requires of us certain ways of acting proper to this caring. Love is about benefiting and being with the loved person, but this requires of us that 
we behave in ways that actually benefit our beloved and make this person appreciate or enjoy our company. Harry Frankfurt has pointed out that love creates some practical necessities:

Insofar as a person loves something, the fact that he cares about it as he does requires that he must care similarly about how he acts in matters that concern it. Because love entails that the lover has certain volitional attitudes toward the object of his love, it also entails that he has corresponding volitional attitudes toward himself. In the very nature of the case, he cannot be indifferent to how what he does affects his beloved. To the extent that he cares about the object of his love, therefore, he necessarily cares about his own conduct as well. ${ }^{9}$

Love, then, imposes on us certain practical requirements: we have to behave in certain ways if we actually want to benefit, and be with, the loved person, and keep her love. That is, we have to behave rationally. Rationality, in the instrumental way in which I am using it here, is a teleological concept, and we use it to design behavior in the light of some goal or end. An act is rational if it tends to promote the achievement of a certain goal, irrational if it tends to frustrate it. A person in love can be called irrational if she tends to frustrate the goals of her love, if instead of benefiting and being with her beloved, she does not procure the other's well-being, and acts to the detriment of the beloved. Then she would be acting against her self-acknowledged own interests. For instance, a man who loves his partner and is reciprocated, and nevertheless deceives her (without there being any stronger reasons than his love for doing so), would fit under this description, since he would be acting against his own acknowledged best interests and undermining his relationship with the person with whom he is in love..$^{10}$

Now, by caring about the other person, and wanting to maintain his love, the lover takes on herself a kind of commitment promise and a responsibility

9 FRANKFURT, Harry. Autonomy, Necessity, and Love. In: Necessity, Volition, and Love. New York: Cambridge University Press, 1999. p. 138.

10 There are all kinds of sick and pathological loves, in which the love of the other person continues regardless of the deceptions, humiliations, ill treatments, beatings, all sorts of domestic violence, and so on, but in these cases either there are other more powerful emotions involved that in the eyes of the beloved justify this conduct and its toleration - such as fear of solitude, guilt for past misdeeds, the belief that beating is a form of caring about the beaten person, etc. - or the loving person cannot properly be called rational. By contrast, in a sadomasochistic relationship, all this behavior would be rational, since it actually tends to promote the pleasure of the beloved, and satisfy her desires, through the infliction of pain, humiliation and bad treatment. To a certain extent, it is this pain and humiliation that constitutes the well-being of the beloved. 
for the other person's well-being. ${ }^{11}$ This is another of the possible rational or civilizing effects of love: it may make people take responsibility, becoming answerable for their actions, and for the well-being and the love of the other person. Love is a form of cooperation in which both partners tacitly agree to be with, and benefit, each other: "to be there for each other," as people say. Romantic love is a kind of promise to do this, and to respond for each other. Unlike other forms of cooperation, one gets into a romantic relationship not exclusively for one's own benefit, but also for the sake of the other person, because one cares about the other person and wants to be with her. But just like any other form of cooperation, this one requires trusting and trustworthy partners - assuming that both partners are actually in love. Love is a kind of commitment promise, but in order to make the promise credible, one has to behave in ways proper to one's love. There have to be grounds for trusting the other. If one does not provide these grounds, it is very likely that sooner or later the beloved will start having doubts that might undermine her love, her interest in being in the relationship, and therefore, her reciprocity. One has to provide these grounds by acting in a rational, and also in a sincere, way, by fulfilling the requirements of love.

To be sure, I do not think that the grounds for love and trust are given entirely by intentional actions or by verbal behavior; our unintentional behavior and our non-verbal communication also play a role when we are in love, through facial and physiological expressions, arousal, and so on, that are also implicated in having this emotion. "To read the emotional configuration of another's body or face is to have a guide to what they are likely to believe, attend to, and therefore want and do," says Ronald de Sousa. ${ }^{12}$ Love, as well as some other emotions, organizes our behavior so as to make it understandable and predictable to others (through our intentional as well as our non-intentional expressions and actions). Only on this basis can we form reliable forms of cooperation, such as the one reciprocal love may create.

3. There is another possible effect that love may have on our rational conduct, and that is actually somewhere in between the spheres of practical and epistemic rationality. For the person who is in love, some of the practical necessities that

11 For more on the commitment model of accounting for rational action see FRANK, Robert Passions within Reason. The Strategic Role of Emotions. New York-London: Norton, 1988; see also GREENSPAN, Patricia. Emotional Strategies and Rationality. Ethics 110 (2000).

12 DE SOUSA, Ronald. The Rationality of Emotions. In: RORTY, A. (Ed.). Explaining Emotions. Berkeley/LA: University of California Press, 1980. p. 138. An empirical rule used in research on communication is that $90 \%$ or more of an emotional message is non-verbal. For the non-intentional and non-verbal aspects of communication, see GOLEMAN, Daniel. Emotional Intelligence. New York: Bantam, 1995. chap. 7. 
love imposes on her may oblige her to have a better knowledge of the nature of her own love and that of her beloved. This knowledge, as a side-effect, would also give her access to a better understanding of other people's similar emotions, since one is better suited to understand other people when they are experiencing love or any other emotion, if one has experienced it oneself. In the first place, love may help to a better self-knowledge: in order to make happy, benefit, or just be with, the person with whom one is in love, and get one's love reciprocated, it is necessary to know the best ways to do it and get to know the possibilities of oneself to do it. If I want to please my beloved, and even change to please her, I have to know myself and my own possibilities for really pleasing her and, if necessary, changing. ${ }^{13}$ Having knowledge of one's own emotions is something that obviously influences the way one acts and fulfills the practical necessities that love imposes on us. Obviously enough, having knowledge of one's own love and of one's own possibilities for fulfilling these necessities influences the way one loves. In a passage of The Art of Loving, Ovid tells us about his encounter with Apollo:
While I was writing this, Apollo suddenly appeared plucking the strings of his lyre with his thumb. (...)
"Professor of Wanton Love," he said to me, "go lead your disciples to my temple,
it's where the famous words, celebrated throughout the world, command everyone to 'Know Yourself'.
He alone will be wise, who's well-known to himself, and carries out each work that suits his powers..."14

He who knows himself may be able to carry out the necessities that love imposes on him in a way that suits his powers. The person who knows himself may be able to love in a way that makes the most out of his own capacities and limitations, and serves better the goals of his love, that is, benefiting and being with the other person. Self-knowledge, therefore, may entail a richer, more rational, love.

Love may not only require a better knowledge of oneself, but also of the beloved. The practical necessities of love may also require that one embarks on a process of knowledge of the other person, and the better one gets to know her, the better one will be able to please and benefit her. One may become more sensitive to certain traces of the other person, to his or her desires, needs and

13 The desire to please the beloved may lead us to change ourselves, and maybe even to remake our selfimage according to how the beloved sees us and to what she expects from and appreciates in us. In this change, I suppose, there should be no imposition on us from the other person.

14 OVID. The Art of Loving. Trans. A. S. Kline. Book II, 493-502. 
interests, to what the other expects from oneself. Love may lead me to adopt the beloved's point of view, and understand how she sees me and how she sees herself. I have to know how she perceives me and what she expects from me. This requires the effort of understanding and deciphering the other person. Of course, in this hermeneutic process, it is hard to know when one gets closer to an interpretation that really fits the object of one's interpretation. At last, this process of interpretation may not only count for a better understanding of the beloved, but as a reflection, of oneself. By understanding the emotions of the other person, one may come to understand one's own emotions better.

4. So far, my emphasis has been on the ways in which love may bring in instrumental or strategic forms of rationality. However, love may rationalize in another sense other than the strategic one. Since rationality is not only a practical, but also an epistemic concept, love may affect it in this other sense. Self-knowledge actually belongs to this category. Epistemic rationality has to do also with discovering in a precise and reliable form the way the world is, with justifying and expanding our beliefs about the world - and also about ourselves. Epistemic rationality has to do with the way in which agents form and justify beliefs - as well as with the consistency of our system of beliefs. Emotions, says Elster, may "facilitate knowledge rather than obstruct it." ${ }^{15}$ Emotions are not always hostile to cognitive endeavors, and the presence of emotions in the process of generating knowledge does not always imply that the resulting beliefs are going to be distorted, biased, or only subjectively justified. ${ }^{16}$ In the case of love, ever since Socrates' discourse in the Symposium, there has been a tradition of poets, writers and philosophers who have emphasized the relationship of love to knowledge and perception claiming that love may lead us to higher forms of knowledge or that it may enhance perception. Octavio Paz, for instance, formulates this idea in the following way: "Talvez amar es aprender / a caminar por este mundo. / Aprender a quedarnos quietos / como

15 Jon ELSTER. Rationality, Emotions, and Social Norms. Synthese 98 (1994), p. 34.

16 Probably the most basic form of involvement of emotions in the formation of knowledge is what people refer to as "passion of knowledge." Not only desire is involved in wanting to discover truth in scientific and other contexts, but also a form of literal passion for knowledge. I interpret this passion not as one, but as a myriad of emotions that are usually implicated in processes of formation of knowledge: hope for the discovery of truth, disgust at fallacious arguments, surprise when something happens that conflicts with prior theoretical expectations, etc. There is a diversity of emotions involved in cognitive processes: hope, fear, pride, admiration, joy, contempt, etc. All these emotions, along with several sorts of practical interests, play an important role as practical stimuli for the generation of knowledge. Israel Scheffler shows "how cognitive functioning employs and incorporates diverse emotional elements". (SCHEFFLER. In Praise of the Cognitive Emotions. In Praise of the Cognitive Emotions. New York/London: Routledge, 1991. p. 3). 
el tilo y la encina de la fábula. / Aprender a mirar." ${ }^{17}$ When we love, we learn to see. For Iris Murdoch, love enhances perception: "Falling in love is very enlightening; for a short while you see the world with new eyes." 18 These writers stress the positive ways in which love may affect perception, and this is the tradition that I want to defend here.

However, there is another tradition that has emphasized the ways in which love distorts perception, which I have called the received view. The traditional dualistic view that keeps emotions and rationality as radically opposed to each other tells us that emotions interfere with the formation and objective justification of beliefs. One's perception of reality tends to be distorted at the heat of lust or a very passionate love (as well as with emotions such as hate, jealousy, anger, or even depression), and the justification of our beliefs tends to serve completely subjective motives. In love one tends to surrender intellectual control and the justification of beliefs, for instance, to wishful thinking and self-deception. ${ }^{19}$ Most of the time it is in the nature of love that our perception of reality and of the beloved be somehow distorted by our feelings. There is truth behind the traditional view of love when it tells us that lovers are not reliable while forming beliefs about the beloved, and while thinking and paying attention, more generally. The image of the distracted lover not paying attention to anything but the object of his love is not casual. "The lover is blinded about the beloved, and prefers his own interests to truth and right," says Plato in The Laws (731e). In this tradition, love is "a bright stain on the vision" and usually takes the form of distorted and biased perception, wishful thinking and self-deception. Probably one of the clearest cases in which love may interfere with the way in which we form and justify beliefs, is what Stendhal calls "crystallization." This is a form of irrational belief formation through which one exaggerates the positive characteristics of the other person, and becomes blind to the negative ones, convinced that the beloved is as wonderful and great as one would like to think of her. "From the

17 "Perhaps to love is to learn / to walk through this world. / To learn to be silent / like the oak and the linden of the fable. / To learn to see." "Letter of Testimony," trans. Elliot Weinberger.

18 I found this quote somewhere on the internet, but I was unable to get the reference; however, similar ideas can be found in MURDOCH. The Sovereignty of Good. London: Routledge and Kegan Paul, 1970, and her Metaphysics as a Guide to Morals. New York: Penguin, 1993, esp. p. 16-17. See also NUSSBAUM, Martha. Love and Vision: Iris Murdoch on Eros and the Individual. In: ANTONACCIO, M.; SCHWEIKER, W. (Ed.). Iris Murdoch and the Search for Human Goodness. Chicago: The University of Chicago Press, 1996. Falling in love may be enlightening, but I am afraid that the same can be said about falling out of love.

19 For more on the effects of love on self-knowledge and self-deception, see VAN FRAASSEN, Bas. The Peculiar Effects of Love and Desire. In: MCLAUGHLIN, B.; RORTY, A. (Ed.). Perspectives on Self-Deception. Berkeley/LA: University of California Press, 1988; and NUSSBAUM, Martha. Love's Knowledge. In: Love's Knowledge. Oxford: Oxford University Press, 1990. esp. p. 274 ff. 
moment you begin to be really interested in a woman," says Stendhal, "you no longer see her as she really is, but as it suits you to see her. You're comparing the flattering illusions created by this nascent interest with the pretty diamonds which hide this leafless branch of hornbeam - and which are only perceived... by the eyes of this young man falling in love." ${ }^{20}$ Love may blind people to certain aspects of reality, making them refuse to see the truth about the other person, and particularly any of her negative characteristics, even failing to perceive aspects of reality that are overshadowed by their love. When madly in love, people may just refuse to see some of the negative features or vices of the other person, justifying her wrongdoings, creating imaginary solutions for any problem between the couple, or even disregarding clear signs of unreciprocated affection or infidelity.

However, as Elster points out in his analysis of the phenomenon of crystallization, this can be contrasted with Stendhal's own novels in which the loved characters are exactly as the loving characters believe them to be. ${ }^{21}$ In The Red and the Black, for instance, it is significant how Julien Sorel perceives very clearly both the positive and negative characteristics of the women with whom he falls in love, Mme. de Rênal and Mathilde de la Mole, without undergoing the process of crystallization or idealization that Stendhal describes in his book on love. The perception that these women have of Julien is equally accurate: despite their passionate love for him they do not fail to perceive his negative characteristics and weaknesses. This is where love may have the positive effects I want to emphasize. Love may redirect perception and enable a better identification of relevant aspects of the loved person; and let me go further and say that it may help us to perceive better some aspects of reality that would pass unperceived otherwise. Love may not only help us to perceive more acutely traces of the character and body of the beloved, but also aspects of the world or objects that may be instrumental in fulfilling the requirements of love: benefiting, or being with, the beloved, or even looking for reciprocity. We may better identify and perceive those objects and situations that the other person needs, desires, or is interested in. All those things are

20 STENDHAL. Romans et Novelles. v. I. Paris: Gallimard, La Pléiade, 1952, p. 287, cited in ELSTER. Alchemies of the Mind, p. 129, see also Stendhal's Love. Crystallization is not a form of idealization. As Tennov tells us: "Idealization differs from crystallization in its implication that the image is molded to fit a preformed, externally derived, or emotionally needed conception. In crystallization, the actual and existing features of [the object of love] merely undergo enhancement. Idealization implies that unattractive features are literally overlooked; in limerence these features are usually seen, but emotionally ignored." (Love and Limerence, p. 31.) "Limerence" is the term she uses to refer to what Stendhal calls "amour-passion," that is, the experience of passionate love.

21 Alchemies of the Mind, p. 129. 
of the interest of the person in love, and may affect the way she perceives those things. Perception can be a function of interest, as much as it can be of expectation: if you expect to see something, or if you have an interest in something, you will see it much more readily. Loving, as a form of caring, is a way of having special interests. You are more perceptive to things when you are interested, or when you care about them and love them. ${ }^{22}$

You actually do not just perceive, but more specifically attend to, aspects of the world and things that are related to your love. By attending, you have a more careful and closer perception of things. Attention is guided by dominant interests that make us recollect certain sets of facts and not others, and observe more closely those things that are in our interest; if there were no presiding interests, we would fail to perceive aspects of reality to which we would be more attentive otherwise. This is William Jame's conception of attention. "My experience is what I agree to attend to. Only those items which I notice shape my mind - without selective interest, experience is an utter chaos. Interest alone gives accent and emphasis, light and shade, background and foreground - intelligible perspective, in a word. It varies in every creature, but without it the consciousness of every creature would be a gray chaotic indiscriminateness, impossible for us even to conceive." 23 If we could not select among the things that we perceive, we would be a sort of automaton reduced to responding to whatever stimulus happened to be the strongest at any moment. Love, and emotions in general, manifest a selective interest that we have for those things we care about and value. Love and emotions, among other things, give a structure, an intelligible perspective, to our experience of the world. Love makes us attend to some aspects of our environment that are relevant to our interests and our love. ${ }^{24}$ I would add: by attending to aspects of

22 There are ways in which our emotions in general, and love in particular, affect and even enhance our perception and our sensory life. This was known by Shakespeare, who tells us that love "adds a precious seeing to the eye: / A lover's eyes will gaze an eagle blind. / A lover's ear will hear the lowest sound." (Love's Labor's Lost act IV, scene 3) In his study on love, Francesco Alberoni also gives us the following description of how love enhances the ways we perceive and attend the world: "At these times, our entire physical and sensory life expands, becomes more intense; we pick up scents we didn't smell before, we perceive colors and lights we don't usually see. And our intellectual life expands too, so that we perceive relations that were previously obscure to us." (ALBERONI. Falling in Love. Trans. Lawrence Venuti. New York: Random House, 1983. p. 12.) Compare to the experiences of the people interviewed by Tennov, op. cit., esp. p. 22. On how emotions may influence, and enhance, some aspects of our sensory life, see NIEDENTHAL, Paula M.; KITAYAMA, Shinobu (Ed.). The Heart's Eye. Emotional Influences in Perception and Attention. San Diego: Academic Press, 1994.

23 JAMES, William. The Principles of Psychology. v. 1. New York: Henry Holt, 1890. p. 402-403. Italics in the original.

24 Cognitive psychology has studied how perception and attention can be influenced by several mental phenomena, such as moods and emotions, that can affect how and what we perceive - let alone how 
reality that may be instrumental to the achievement of our goals, and by acting on the basis of that information, we are not only fulfilling the requirements of love, but we are acting rationally.

While directing our attention, emotions frame our perception by defining the parameters taken into account in any particular process of knowledge, but also by bringing into light only a small portion of the available information. They narrow down the number of considerations relevant to knowledge and provide the framework within which the process of knowledge takes place. The same might be claimed about the process of practical deliberation and the rational decisions we take: emotions frame our decisions by defining the parameters taken into account in any particular deliberation. As De Sousa tells us, emotions limit "the range of information that the organism will take into account, the inferences actually drawn from a potential infinity, and the set of live options among which it will choose." 25

We not only perceive and attend more easily to things that we would not have perceived otherwise, but I take it that these cognitive processes may also help us to understand better and give new meaning to things that we may not have apprehended before. Particularly relevant, I think, is the case in which we give a new or a different value to things that did not have any meaning to us before, such as specific traces or features of the other person, like in the case of Julien Sorel, who, once in love, discovers traces of character of his beloved that were previously obscure to him, even after knowing the other person for some time. One may also discover the virtues of the beloved; Ralph Waldo Emerson tells us about this: "He who is in love is wise and is becoming wiser, sees newly every time he looks at the object beloved, drawing from it with his eyes and his mind those virtues which it possesses." ${ }^{26}$

However, some questions remain: how can we know that we are really attending to the right evidence for the justification of our beliefs about the other person or about the world and not too selectively focusing on positive aspects and overlooking other aspects that might be relevant, such as vices and

background abilities and our Weltanschauung can affect the way we perceive and attend. Emotions and interests also have a role in cognitive functions such as learning and memory that may be enhanced by this process of attention. For more on this topic, see Basic Behavioral Science Research for Mental Health. A Report of the National Advisory Mental Health Council, NIH Publication No. 96-3682, 1995. See also DAMASIO, op. cit., p. 173.

25 The Rationality of Emotion. Cambridge, MA: The MIT Press, 1987, p. 195. This position has been called the "search hypothesis of emotion", and it has been criticized by Dylan EVANS. The Search Hypothesis of Emotions. British Journal of the Philosophy of Science 53 (2002), who argues that it needs to be supported by a theory of what emotional mechanisms really are so that they are capable of having this effect.

26 EMERSON, Ralph Waldo. The Method of Nature. Delivered to the Society of the Adelphi, Waterville College, Me. (Published in The Works of Ralph Waldo Emerson, 1889). 
weak spots of the beloved? How can we know that we have reached a balance between our beliefs about the beloved and the actual person? How do we know that we are getting things right, and that our beliefs are true and our perception reliable and that we have not entered into a process of crystallization (selfdeception or wishful thinking)? This is very hard to know, if not impossible from the perspective of the first person, the lover. But I do not think that a thirdperson point of view can be of much help either, since many of the virtues of the other person and those things that the lover more readily sees are evident only to him. The lover has to know himself and his beloved very well in order to know when he is deceiving himself or crystallizing, and when his beliefs based on love are accurate and properly justified. Perhaps some of his beliefs will be product of the former process and some of the latter. Love in fact tends to interfere with the way we form beliefs and perceive the world, through crystallization and self-deception; but even then, there are certain spots in perception and action where love may help the rational formation of beliefs. Ultimately, rationality is not a wholesale phenomenon that encompasses all of our thoughts and actions, but one that works more in a molecular way. While we are irrational in some aspects of our life, we are rational in others; while there are mechanisms in which emotions trigger irrational effects, there are some others in which effects are rational, given the way in which emotions aid a more accurate formation of beliefs. While some of our beliefs about the other person may be due to crystallization and self-deception, some others may be true and well justified. Yet, sometimes the line between these two is not as clear as one would like it to be.

As I said before, the cases I have described are just a different mechanism to the one the received view of love has emphasized. Love may trigger these two alternative mechanisms, and it is hard to know why one is brought about rather than the other. Many would say that the cases I have described are probably not the rule, but exceptions; but even then, the kind of mechanism I have described, rather than obstructing rational thinking, facilitates it. The interrelations of reflective thinking (either theoretical or practical, if we want to keep this distinction) and emotions are more complex than what one would at first think. ${ }^{27}$

27 Earlier versions of this paper were presented at a group session at the Eastern Division Meeting of the American Philosophical Association, and at a colloquium of the Instituto de Investigaciones Filosóficas, Universidad Nacional Autónoma de México. I owe thanks to audiences at these places. Special thanks to Eleonora Cresto, Guillermo Hurtado, Laura Duhan Kaplan, Gurpreet Rattan, and Rasmus Winther for useful criticism. I wrote a first version of this paper as a member of Jon Elster's seminar on emotions at Columbia University. Thanks are also due to professor Elster. 